student, who were killed while working in Nigeria/Biafra as volunteers for the Save the Children Fund.

\section{Mental Health Research}

With inflation at its present rate, says the Annual Report of the Mental Health Research Fund, each year $20 \%$ more money must be raised just to continue the support of a constant volume of research. Projects of high scientific merit are being turned down for lack of funds. Among research currenly receiving support is a study of the biochemistry of schizophrenia at Edinburgh; investigation of infant behaviour at Cambridge; and work on psychogenic amenorrhoea. Grants approved in the year totalled $£ 87,147$.

\section{Bangladesh Medical Association}

East Bengal doctors in Britain have formed the Bangladesh Medical Association to send medical aid to help the people of East Bengal. Further details are available from the joint convenors, Drs. A. T. M. Z Chowdhury and Altafur Rahman at 9a Wotton Road, London N.W.2.

\section{People in the News}

Lord Kindersley has been appointed president of the Arthritis and Rheumatism Council, in succession to the late Dr. W. S. C. Copeman. Until his resignation last year Lord Kindersley had been chairman of the Review Body on Doctors' and Dentists' Remuneration since 1962.

Emperor Hirohito of Japan has been elected a Fellow of the Royal Society.

\section{COMING EVENTS}

Royal College of Physicians of London.Teach-in "Treatment of Cardiac Infarction," 1 June, 8 p.m. For details see advertisement on page xiv.

Summer School in Health Physics (Radiation Protection). - 28 June-9 July, Imperial College. Fee $£ 40$ (including lunches). Details from Dr. H. D. Evans, Nuclear Technology Laboratories, Department of Chemical Engineering and Chemical Technology, Imperial College, London S.W.7.

International College of Angiology.-Annual meeting, 29 June-4 July, Copenhagen. Details from the college, 381 Park Avenue South, New York, N.Y., 10016, U.S.A.

Manchester University Department of Obstetrics and Gynaecology.-Short course, "Reproductive Physiology," 30 June-2 July, St. Mary's Hospital. Applications, by 21 June, to the dean of postgraduate medical studies, Manchester University, Manchester M13 9PL.

General Practitioner Research Club.-Seventh meeting, 3 July, Swansea. Details from Dr. R. C. Fraser, 28 Uppingham Road, Leicester.

"Environment and Health-Modern Perspectives in Human Ecology."-Conference, 6-8 July, Reading University. Details from Dr. A. Gatherer, Bristol and West House, 173/174 Friar Street, Reading RG1 1JB.
Society for the Study of Inborn Errors of Metabolism.-Annual symposium, 8-9 July, Leeds, Yorks. Details from Dr. K. S. Holt, Wolfson Centre, Mecklenburgh Square, London WC1N 2AP. (Tel. 01-837 7618.)

Institute of Religion and Medicine.-Annual assembly and conference, "Groups and Teams in Medicine and Ministry," 13-15 July, Norwich. Application forms and details from Miss $M$. C. Kidson, at the institute, 58A Wimpole Street, London W1M 7DE. (Tel. 01-935 4687.)

\section{SOCIETIES AND LECTURES}

For attending lectures marked a fee is charged made first to the institution concerned.

Tuesday, 1 June

Institute OF DeRmatology.-4.30 p.m., Dr. P. F Borrie: Cutaneous Vasculitis.

Royal Army Medical College.-5 p.m., Professor S. Shuster: Sweat and Sebum.

Royal Postgraduate Medical School. 4 p.m. Professor L. Van der Hauwaert (Louvain)
Arterial Blood Supply to Sinus and A-V Node.

\section{Wednesday, 2 June}

Institute OF Psychiatry.-5.30 p.m., Dr. D. Lcigh Some Psychiatric Aspects of Murder.

King's COllege Hospital Medical SCHOOL.-4.30 p.m., Legg memorial lecture by Professor J. C Goligher: Crohn's Disease with

OXFORD UNIVERSITY.-At Radcliffe Infirmary, p.m., Dr. W. E. Ormerod: Trypanosomiasis.

ROYAL FREe Hospital.-5.15 p.m., Professor J Pepys: Clinical Immunology of Allergic Lung

Royal Postgraduate Medical School.-11.45 p.m Professor P. G. H. Gell, F.R.S.: Classification of Allergic Reactions.

Royal Postgraduate Medical School. -5 p.m. Professor L. Van der Hauwaert (Louvain):

\section{Thursday, 3 June}

Honyman Giliespie Lecture.-At Royal Infirmary, Edinburgh, 5 p.m., Mr. J. Lister: Myelomeningocele-Management and Outlook in 200 Cases.

ST. BARTHOLOMEW's HoSPITAL.-At experimental pathology block, 5 p.m., Dr. I. A. Jaffe (New York): Penicillamine.

St. Mary's Hospital Medical SchOol.-5.15 p.m Mr. S. Wood: Oestrogen and Tryptophane Meta-

WestMinster MEdical SCHOOL.-5.15 p.m., Mr. I

\section{Friday, 4 June}

Royal Postgraduate Medical School.-11 a.m. Mr. C. Wastell: Duodenal Ulcer-a continuing Challenge.

Royal Postgraduate MEdical School. 5 p.m. Professor L. Van der Hauwaert (L

Saturday, 5 June

Cambridge University Medical School.-At Addenbrooke's Hospital, 10.30 a.m., day symposium: Paediatrics."

\section{APPOINTMENTS}

EAst ANGlian Regional Hospital Board.-N. K Coni, M.B., F.R.C.P.(C.) (consultant geriatrician, Newmarket General Hospital and United Cambridge Hospitals); C. Hodgson, M.B., F.F.A. R.C.S. (consultant anaesthetist, Ipswich group H.M.C.); K. W James, M.B., F.F.R. (consultant radiotherapist, (consultant physician, Norwich, Lowestoft and Great (consultant physician, Norwich, Lowestoft and Great
Yarmouth H.M.C.); P. Sykes, M.B., D.P.M. (consultant psychiatrist (mental subnormality), Peterborough District and Ida Darwin Hospitals).

Wessex Regional Hospital Board.-P. J. Fenton, M.B., F.R.C.S., D.O. (consultant ophthalmologist, Portsmouth group); A. J. Harbott, M.B., D.P.M (consultant in adolescent psychiatry, Knowle group, Hampshire Child Guidance Service); G. Kerr, M.B.,
D.P.M. (consultant psychiatrist, mental handicap, D.P.M. (consultant psychiatrist, mental
Coldeast and Tatchbury Mount group).

\section{UNIVERSITIES AND COLLEGES}

\section{CAMBRIDGE}

M.D.-M. J. Raphacl, G. C. Sutton, E. R Williams.

\section{LONDON}

The title of rcader in morbid anatomy has becn conferred on Dr. P. M. Sutton in respect of his
post at University College Hospital Medical School. LIVERPOOL

Appointments.-Dr. I. C. Geddes (reader in anaesthesia); Dr. D. Hobson (reader in medical microdocrine pathology); $\mathrm{Dr}$ K $\mathrm{K}$. Neame in enlecturer in physiology). ROYAL COLLEGE OF SURGEONS OF

At a meeting of the college held on 14 May, with Professor D. M. Douglas, president, in the chair, the

S. C. Agarwal, A. T. Md. Shamsul Alam, M. Ali, W. S. Ali, K. K. Aravindakshan, Swaran L. Arora, hury, J. R. Curtis, J. N. Douglas, J. R. Elder, R. M. hury, J R. Curtis, J. N. Douglas, J. R. Elder, R. M P. J. Farrell, R. D. Finlay, W. D. Fisher, J. H. Fleming, J. Freedman, H. H. A. Gawish, S. K. Ghosh, L. A. R. Graham, N. S. Gundara, K. S. Hasan, B. S. H. Hawkins, (Mohamed Sabry), P. A. C. Induruwa, N. L. Jha, A. M. B. Johnson, A. O. B. Johnston, S. A. Kabir,
V. R. Kale, M. N. Khan, Chong Yew Khoo, C. S. Krishnamoorthy, D. R. M. K. Moorthy, A. Kumar. S. Kumar, D. C. Lambert, Seek-Kee Leong, J. P Mayers, U. Mendis, S. S. El Abd Mahdi, F. N R. Murali, T. C. Nagaraja, S. H. P. Nathwani, R. O. Ofoegbu, A. H. M. Osman, S. Pathmayokan, R. N. Phade, M. S. Ponnampalam, D. K. Prajapat, R. M. Pringle, L. A. Quadery, N. Ramachandran, M. R. Raouf, P. Ratnesar, A. C. Ray, R. N. Ray, A. Resouly, M. S. M. K. A. Samaratunga, C. T. M. Sang, J. P

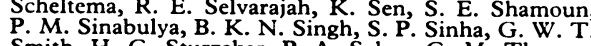
Simith, H. G. Sturzaker, P. A. Sykes, G. M. Thomas, A. Leung-Chui Tsui, A. R. Turner, M. A. Walsh, ROYAL COLLEGE OF SURGEONS IN IRELAND F.F.A. R.C.S.I.-Barbara J. Burbridge, Margarct maran.

\section{CORRECTIONS}

\section{Bacteriuria Again}

In a letter by $\mathrm{Mr}$. J. C. Gingell ( 1 May, p. 278 ) in the third line the word "generation" was inadvertently printed. It should have been "gentamicin". Half way down the first paragraph a percentage sign was omitted. The sentence concerned should have read "More than 50 "' of the few reported patients with ototoxicity due to gentamicin ..."

\section{Resuscitation of Drowned Children}

In a letter by Mr. J. R. Gibbs (22 May, p. 470) we regret an error printed in the acknowledgement. This should have read "Rear Admiral Stanley Miles, consultant in physiology to and vice-chairman of the Medical Commission on Accident Prevention ..."

\section{Notice to Authors}

When original articles and letters for puhlication arc not submitted exclusivcly to the British Medical fournal this must be stated.

Correspondence on editorial business should be addressed to the Editor, British Medical fournal, B.M.A. House, Tavistock Square, London WC1H 9JR. Telephone: 01-387 4499. Telcgrams : Aitiology, London, W.C.1

Authors wanting reprints of their articles should notify the Publishing Manager, B.M.A. House, Tavistock Square, WC1H 9JR, on receipt of proofs. 